DOI: https://doi.org/10.3126/njdrs.v18i01.41946

\title{
Women Participation in School Governance in Lalitpur, Nepal: A Participatory Development Practice
}

\author{
Rishi Adhikari ${ }^{1}$, Devendra Adhikari ${ }^{2}$ \\ The authors are MPhil graduates in Development studies from the Kathmandu University, School of \\ Education, Hattiban, Lalitpur, Nepal. \\ Email: adhikaririshi99@gmail.com \\ Correspondence should be addressed toDevendra Adhikari; devendra.adhi84@gmail.com
}

\begin{abstract}
Participation is an important dimension of good governance. In Nepal, there seem positive changes in women's participation in School Management Committees (SMC), Parent Teachers Association (PTA), and school administration but the participation of women has become a far-reaching goal in public school governance. This article is about exploring how women's participation could contribute to promoting good governance practices in community schools. Authors have applied an interpretative inquiry and participation and feminist standpoint theories to make out the meaning in this study which was carried in two public schools in Lalitpur, Nepal. The finding reveals that his meaningful representation of women in school governance is likely to minimize the governance challenges such as absenteeism, low parents' participation, poor resource mobilization, transparency, and accountability. These positive transformations contribute to the community development process. However, enabling environment for women is needed to ensure their meaningful representation in school governance structures. This study is beneficial to educationists, planners, and development workers in Nepal.
\end{abstract}

Key words: Women participation, public education, good governance, development

\section{Introduction: Women Participation in School Governance}

Participation is one of the important elements of good governance. Nekola (2006) states that good governance is associated with decision-making processes and ensuring effective implementation associated with the government and public administration. Good governance is defined as the exercise of authority through formal and informal traditions and institutions for the common good which encompasses the process of selecting, monitoring, and replacing governments; the capacity to formulate and implement sound policies and deliver public services; and respect for citizens. Thus, women participation in school governance is helpful to

Good governance has different key indicators that cause better performance and results of the organization. School governance also includes some indicators which are also known as the elements, principles, and components of good governance. These key indicators are accountability, participation, equity and inclusiveness, transparency, rule of law, effectiveness, and efficiency, and responsiveness (Mercy Corps, 2009). Participation is a significant one that is taken as the cornerstone of good governance. Participation can be either direct or through legitimate intermediate institutions or representatives. Authors consider participation in school governance as a strategy for including the people

Nepalese Journal of Development and Rural Studies, Volume, 18, 2021 
who have been excluded, marginalized, and not acknowledged by society, governmental, and nongovernmental agencies through information sharing. Precisely, the school governance includes the indicators: resource management (fundraising, providing services, managing teachers and staff), peoples engagement (participation of parents: men and women), and institutions improvement (reducing nepotism, absenteeism of teachers and students, improving the performance of teachers and other stakeholders, controlling corruption and fraud, etc.) and promoting accountability and transparency (Lewis \& Gelander, 2009). It is about the formulation and adoption of policy and management for the day-to-day delivery of education and decisions are made with the involvement of relevant stakeholders (Maile, 2002). Authors acknowledge the participation of relevant stakeholders in decision-making, where the decision-makers are accountable to provide quality education for all the students. Participation is the people's engagement in any group, network, institution, and development process throughout the planning, designing, and implementation. In the context of this research, the authors believe that participation is related to the women's engagement in the governance process (including SMC, PTA, administration, etc.) of school.

\section{Role of Women Participation: Ensured or Pseudo?}

I (Principal author) have experienced and observed women's participation in school governance and development process, during my profession as a teacher and development worker. Most women are engaged in household chores and subsistence productions and farming. Women are largely dependent on men which seems to create barriers to participate in the outside world with the market, economy, legal actions, and social actions (Haug \& Aasland, 2015). In contrast, a very limited number of women have been engaged in educational institutions, community-level groups, social actions, and local development processes who generally listen to the voices (latent and manifest) and witness the activities of males and follow their command and working pattern. They are able to accept the decisions made by the male who has more influence and power that can manipulate the planning, decision, and implementation of the plans and decisions which are guided by our patriarchal societal beliefs and ethics (Pandey, 2016).

The constitution of Nepal 2015 has provisioned women's right to participate in all bodies of the State based on the principle of proportional inclusion. Women also have an endowment of the right to obtain special opportunities in education, health, employment, and social security. Similarly, article 12 (1) of Education Act 2028 (1971) 8th amendment 2016 has provisioned at least 33 percent (3 out of 9) women in the SMC. However, only 22.1 percent of women have participated in the SMC (Ministry of Education, 2016b). Moreover, School Sector Development Plan 2016-2023 has also provisioned the equal participation of marginalized groups i.e., women, people with disabilities, indigenous people, and people having the poor economic condition. Regarding participation, this plan provisioned equity as a key dimension that aims to ensure an inclusive and equitable system in terms of access, participation, and learning outcomes. Its focus was on reducing disparities among the people who have the lowest levels of access, participation, and learning outcomes.

However, the low representation of women in the school management structure is interwoven with their meaningful participation and the inclusive development of the education sector. Although, the government policies in Nepal (Ministry of Education, 2016a; Ministry of Law, Justice \& Parliamentary Affairs, 2015, 2016) are claiming for ensuring the minimum percentages of women in any social organization in the country, the same is not reflected in the practice (Joshi, 2018; Sijapati, 2019; Thapa \& Pathranarakul, 2019).Some of the scholarly research points out that women's participation in different government and non-governmental structures in Nepal is very low and not much influential in the decision-making process (Joshi, 2018; Sijapati, 2019; Thapa \& Pathranarakul, 2019). Women's participation could not be enhanced as expected by the policy provision due to the weak school governance mechanism. Munakarmi (2015) reveals those weak mechanisms of school governance, and hegemony and superiority thinking of school administration could not create an enabling environment for 
better participation of parents. The school governance has not created a conducive environment and supportive mechanism to enhance the participation of the parents including women as well.

Besides, there were no elected representatives at local levels to institutionalize the inclusive school decentralization practice in the country from 2002-2016 (Chetri, 2017; Shrestha, 2014). School Sector Reform Plan (2009-2015) had high expectations from local governments in terms of providing quality education service delivery and leading the school management committees. However, it remained unfulfilled due to the unstable political climate and weak governance structure centrally and locally (Ministry of Education, 2009). The local election was held in Nepal in 2017, after two decades. The people's representatives have been learning different local development practices including participatory school development. It is stressed in the School Sector Development Plan (Ministry of Education, 2016c). These developments show weak governance systems were in practice in the past and there has been a low representation of women in school management structures. Thereby, there is very limited or even no research in the context of exploring the role of women's participation in school governance in Nepal. Thus, the purpose of this study is to explore how women's participation can contribute to promoting good governance practices in public schools in Nepal.

\section{Theoretical Insights: Participation Theory}

Genuine participation requires citizens' capacity to choose their roles and use of their power in decision-making, whereas it is not the real participation when just decisions are informed to the citizens, placate their complaints, and manipulate their opinions (Wang, 2001 as cited by Khanal, 2013). It is the practice of knowledge and capacity through engagement in different structures: committees, organizations, groups, networks, associations, and local level planning and school development process. Participation, in line with these approaches and practices, has been theorized by different scholars. Arnstein (1969) defines participation as the hierarchy of power for people. She concludes that participation in the strategy for joining those have-nots through information sharing, preparing plans and policies, access and control over the resources. Gaber (2019) asserts that participation in the redistribution of citizen's power supports the powerless, marginalized, left behind people to get power and can realize their expected goal in the community and institutions. Participation theory presented a typology of participation as a supportive tool to analyze knowledge, engagement, and level of participation of women in school governance structures (SMC, PTA, and school administration) for my research.

\section{Standpoint Theory}

The standpoint theory is directly connected to knowledge production from women's perspectives is dominant and significant to my research. Pandey (2016) articulates that feminist standpoint theorists believe in diversity among women. It believes in experiences and knowledge that varies due to unique socio-political and economic background and focuses on gender mainstreaming in all sectors of social structure and recognition of women's leadership and knowledge.

Standpoint theory brings about the relations between knowledge production and practices of power to a level of discourse. It is not just an explanatory theory, but also prescriptively a theory suggesting a method to guide feminist research (Harding, 2004). This includes suggesting ways to empower oppressed groups including women, valuing their experiences, and initiating to take action to develop an oppositional consciousness (Collins \& Sandoval, 1989 as cited by Harding, 2004). Different authors have taken it as a philosophy of natural and social sciences, an epistemology, a methodology of research, and a political strategy. This theory is an appropriate tool for social transformation. Regarding the relevance of the application of this theory in the context of Nepali Society, although many laws and policies have been changed recently based on viewpoints of gender equality, Pandey (2016) claims that it is still dominated by patriarchal norms and values in practice. The feminist standpoint is the key aspect in 
the research process to mainstreaming knowledge, skill, and experiences of women from marginalized, oppressed, and subordinate groups.

Interpretative Case Study Design

As the purpose of this research is to explore contributions of women's participation in school governance, this research aims to explore multiple realities based upon the life experiences of the research participants. Thanh and Thanh (2015) state that the interpretive paradigm focuses on the experience and perception of individuals which allows researchers to interpret the world through the perceptions and experiences of the participants in a particular background. This study applies the case study approach (Yin, 2014), which seeks the subjective interpretation of participants and experiences regarding women's participation in school governance. Field information was collected through observations, interviews, school documents review, and was thematized to make out the sensible meanings.

This study was conducted in the two public schools in an urban (Jwala Secondary School- JSS) and a semi-urban (Triratna Secondary School- TSS) localities in Lalitpur, Nepal. The participants of this study were the relevant school holders such as SMC and PTA representatives, teachers, and head teachers who were selected purposively for this study. The schools are considered as research units or sources of information in this research. The participants are Ms. Sabina (ahead teacher, JSS), Ms. Kunta (an SMC member- JSS), Ms.Bika (deputy head teacher and teacher representative in SMC- JSS), Mr. Medi (a head teacher, TSS), Ms. Mila (an alumni, TSS), and Ms. Mitra (an SMC member).

\section{The Findings: Women Participation for Promoting Governance of Community School}

This section includes field observation and sharing by theparticipants regarding the contributions of women's participation in promoting governance inpublic schools. The findingcomprises threeconceptual blocks: participation leads fund-raising, safe schools, and participation.

Participation Leads Fund Raising (Contributing towards Improved Governance). JSS is situated in an urban settlement in Lalitpur. During the field visit in the school, I (Principal author) observed the stone plagues, which included the name list of the donors who had financially supported the school. There was the name of one of the research participants, Kunta, who is an SMC member. Financial resource is an important component required for operating school administration smoothly and promoting the overall governance situation of the school and any organization. Regarding this, a participant, Kunta added:

We collect donations from different non-governmental agencies, the government also provided the grant, and student play Deusi and Bhailo ${ }^{1}$ to collect financial resources for the school.

(Kunta, a SMC member, JSS)

The availability of the resources has made JSS easy to manage educational materials such as computers, lab, reading materials, and organizing extra classes for poor students. These educational interventions have contributed to improving the learning environment. Kunta herself has provided some monetary support to the school and purchased educational materials for unprivileged students.

Bika shared that she had facilitated to build of separate toilets for both teachers and students which were gender friendly. She takes care of the waste management system in the school. She shared:

I have been coordinating with different stakeholders, parents, and donors for doing financial support to construct the school building, purchasing furniture, and paying teachers' remunerations on time. We also have to look after other school expenditures such as sports and extracurricular activities. I have established a fund for providing scholarships to needy students.

(Bika, Deputy Head teacher, JSS)

Bika has been promoted as a deputy head teacher in recent years. After she got opportunities to lead the school administration, she initiated to support the school stakeholders. She facilitated organizing capacity-

\footnotetext{
${ }^{1}$ This is a play performed during the Tihar festival in Nepal. Nepalese Journal of Development and Rural Studies, Volume, 18, 2021
} 
building training for teachers, raising funds for the school, and arranging facilities for girls' students in the school. An SMC member, Sabina has also concerned about the fund raising in the school. She mentioned that financial management is the key focus in the school meetings and discussions of SMC. She expressed:

The financial management includes managing teachers' salaries, expenditures for extra-curricular activities for sports, exposure visits, speech, quiz context, etc. We also provide midday meals for children with the support of the local government. We accept the donation from I/NGOs, parents, and Lahures ${ }^{2}$.

(Sabina, SMC member, JSS)

The changes in the JSS were visible during the time of the field study. The school was capable of buying on, developing infrastructures, managing privately funded teachers and other staff's salaries, providing scholarships to needy students, arranging the educational visits, and organizing extra/cocurricular activities and sports.

In the case of TSS school, Mr. Medi, the head teacher shared about the role of Purba Bidhyarthi Samiti $^{3}$ in the school which is also contributing to fundraising. This Samiti is an eleven membered team in which there are four females. This is the only gender-inclusive committee in the school, as shared by the head teacher. Medi elaborated:

Alumni was established in 2066 BS [2010] aiming to support the school to improve the educational quality and to transform this school into a renowned community school in the region. The president has a good network and relationship with different social clubs such as Rotary, scout, and others. The Alumni team is helping their past school selflessly.

(Medi, head teacher, TSS)

Medi mentioned that, because of the engagement of the alumni in the school, the concern of local stakeholders to the school has been increased. Alumni members make a visit to school time and again, providing education materials to poor students, and organizing different functions as well. He added:

Last month they painted the walls of classrooms free of cost. They are engaged in different governmental and non-organization which have also become good platforms for supporting the school.

(Medi, head teacher, TSS)

In this regard, Mila, who is an alumni member of TSS added that:

Within a year, we colored the school buildings, conducted an award ceremony function for bestperforming teachers, organized picnics for recreation, and provided financial support to the school. We are further discussing to enhance the performance of the school for making ita model community school in this locality.

(Mila, Alumni member, TSS)

Participation of women in public service sectors such as public education certainly enhances the governance system of the institution through the increased social networks. The social network in the study schools was utilized to collect funds for the school. Participation has been contributing to raising the fund for the diverse purpose of the study schools, for instance for infrastructure development, paying remuneration of teachers, the cost for daily administration, scholarship, educational materials, daily meals for the students studying in lower grades, and extracurricular activities. The research participants claim that due to the proper use of available funds, the governance situation of the school has been improving. Thereby, the role of women's participation is helpful to bring significant changes through resource mobilization in the public education system in Nepal.

\footnotetext{
${ }^{2}$ Lahures are the Nepalis who work in foreign armies (ex or current), usually in British, Indian, and Singapore

${ }^{3}$ Alumni
}

Nepalese Journal of Development and Rural Studies, Volume, 18, 2021 
Safe Schools (A Significant Component of Good Governance). A safe learning environment and appraising cultural values are more concerned about the safety and wellbeing of the students. These indicate that females' friendly environment and culture in the school have improved the performance of students and enhanced the governance situation of the school. During the field visit, I (Principal author) observed the CCTV Cameras installed in the JSS to monitor the activities of students, teachers, parents, visitors, and other relevant stakeholders in and outside the school premises. It has become a powerful means to monitor the students' safety and control outside people from wrongdoing in the school premises if any. Kunta exposed:

The activities of the visitor and other people outside the school premises are also inspected by CCTV cameras. The activities of students are also observed through the cameras for their safety.

(Kunta, a SMC member, JSS)

The JSS school has installed a complaint box and formed a complaint handling committee which is led by a female teacher. I (Principal author) observed the record of complaints collected through different channels including the complaint box of the school. The complaint box was lying on the walking passage due to the ongoing school construction works. There was a complaint handling mechanism comprising a response committee led by a female teacher. For the well-being of the girls' students, well-managed menstruation and hygiene services have been practiced in the JSS. Due to this, students feel safe and attend school regularly and participate in the teaching-learning process comfortably. Bika is playing a lead role in the JSS in managing menstruation-related sanitation and hygiene practices at school. Regarding this she shared:

I facilitate the management of separate toilets for male and female teachers and students at school. Generally, females need more water than males while using the toilet. They need a separate room for changing sanitary pads. In the past, the waste of the sanitary pad used to be thrown randomly outside the toilet. No dustbin was kept. I facilitated managing dustbins. I started counseling girls to use those dustbins. I led to manage sanitation materials such as bucket, soap, jug, and improved waste management system.

(Bika, Deputy head teacher, JSS)

The above narrations of Bika reflect that the facilities related to sanitary and hygiene including menstruation hygiene practices are the key factors to increase attendance of women and girls in schools. I (Principal author) also observed the sanitary services were provided by the school. There were separate toilets for males and females with water services. There was a service for a filtered drinking water system for students, teachers, and others. These inclusive changes seem to have developed the confidence of girls to engage in the teaching-learning process. Terry and Thapa (2012) have similar opinions regarding the necessity of facilities of sanitary and menstruation hygiene in school. Terry and Thapa assert that many schools do not have such facilities which impacts girl students either to remain absent or leave the classes.

As Medi shared, the TSS also has seriously undertaken the safety issues of students and teachers. His team has started a complaint hearing mechanism and management of sanitation and menstrual hygiene practices in the school. Medi revealed:

We have a complaint box for students which I installed when I became head teacher. Teachers and other staff can complain to the academic in charge or sometimes directly to the head teacher or chairperson of the SMC. School has assigned a teacher to maintain the logbook to register all these grievances. The complaints from students are addressed by the school administration including the principal, representatives of child clubs, and teachers. Complaints of teachers are addressed either by the principal or SMC. If the complaint is about the head teacher, SMC will address the complaint.

(Medi, head teacher, TSS)

Nepalese Journal of Development and Rural Studies, Volume, 18, 2021 
Medi also disclosed a female teacher has been assigned as a focal person for collecting issues and complaints relating to female teachers and staff. This is because girls feel comfortable sharing their grievances with females rather than males, as shared by Medi. He further elaborated:

I (Principal author) do a review of the complaint records and our Complaint Response Committee responses to all these issues. The complaints from students, teachers, parents, and other stakeholders are collected in a complaint box kept on the school premises.

(Medi, head teacher, TSS)

To encourage girls to attend school regularly, the TSS school administration was planning to install vending machines to distribute free sanitary pads that were donated by different stakeholders including the local and central government agencies. The school was working out to manage separate changing rooms for students. School structures were being built friendly to people with disabilities, children, and female students. About the services about sanitation and hygiene, Medi stated:

Due to the lack of space, because the school building is under construction, we are distributing sanitary pads manually. Otherwise, we are planning to keep vending machine to distribute the pads. We do not lack sanitary pads. We have a counseling room where the girls take a rest if they feel pain during the menstruation period. In the room, other students also can take rest and get first aid if they get an injury due to many causes.

(Medi, head teacher, TSS)

I (Principal author) observed the sanitary services available at the TSS school. There were separate toilets for males and females, and separate water taps for sanitation services and drinking. There was a restroom where sanitary pads and first aid kits were stored. The pads were distributed to the girls based on their needs during the menstruation period.

Overall, the participants in this research have importantly raised the safety and wellbeing of girls' students and have succeeded to materialize it. As per the observation and sharing by the participants, the safety measures applied in both the schools have been encouraging girls to attend school regularly. These all factors seem to have been contributing to improving the governance situation in the study schools. The inclusion of women in school structures such as teaching jobs, SMCs, alumni, and so on has contributed to promoting a safe school environment for girls and others.

Participation (Creating Space for Self-empowerment). We always believe that participation is helpful for organizational development, but participation can benefit women's empowerment as well. Women's participation in any group, organization, and network helps to develop their capacity. It contributes to enhancing the socio-economic and political status and balancing gender relations in the context of Nepal. Participation is a key driver to empowerment and a tool for reshaping life (Saud, 2020). In the initial phase of participation, people do not have the power to influence the decision and to lead the group, organization, and networks. Bika has a similar understanding and experience. Regarding this, she asserted:

We must create our space ourselves. I always remain supporting the head teacher to perform daily actions of the school, to operate school administration, and to improve the teaching-learning environment.

(Bika, Deputy head teacher, JSS)

Bikaunveils that if women's participation is strong, they can negotiate for equal remuneration and raise voices against gender discrimination. Women should participate in each sector, for instance, social, political, economic, and cultural which would help in their fair and equitable development. Bika added:

I think, if women participate in each action wherever they are invited, they can claim their rights and raise their voices for their betterment. They can vocalize their issues, put demands, pressure for fulfilling requirements, and influence the decisions making processes.

(Bika, Deputy head teacher, JSS)

Nepalese Journal of Development and Rural Studies, Volume, 18, 2021 
Bika's claim signifies that women's participation in any social institution empowers them so that they can advocate for their rights, services, and social justice in the broader perspective. Rimal (2018) unveils that women's participation is a basic human right, whichthey should optimally utilize by taking part in the decision-making and implementation process. Women's roles are also crucial in the education system which could be both teaching and learning, and school governance. Bika has also had the same kind of experience as she remains close with the head teachers. She has been engaging in each activity of SMC, PTA, and school administration. This dynamism has become a good platform for herself-empowerment.

Kuntahas her own experience regarding participation in social networks. She has empowered herself through her participation in different forums. She shared that she visited many countries in the world when her husband was serving in the British Army. During her visits, she got diverse experiences and exposure to the culture, values, and educational practices of those countries. Kunta shared that:

I stayed in the United Kingdom for several years with my husband. After returning to Nepal, my community people chose me as the chairperson of the Community Development Committee. Afterward, local political leaders and another stakeholder of the school requested me to be the chairperson of SMC, but I gave up the proposal. I realized that I could not contribute much to perform my roles as the chairperson as I had to engage in other social forums as well.

(Kunta, SMC member, JSS)

Kunta persuaded the better socio-economic position, and the parents, teachers, and other stakeholders realized her necessity in the SMC. School stakeholders nominated her as an SMC member for two tenures through common consensus. She has a good influence on SMC and its decision-making process too. This indicates that she prepared herself as an empowered woman. It might have been possible due to her interaction, exposure, and participation in different social networks.

Mitra has participated in the SMC for the first time. Hence, she has limited experience in participation, but she believes that she will get knowledge and empowerment herself through her participation in different activities and meetings of SMC. She expressed:

I became a member of SMC to get knowledge, learn about women's issues, and empower myself and other women.

(Mitra, SMC member, TSS)

Mitra perceives that participation in SMC as a learning platform that could contribute to her empowerment. Anyway, the SMC forum is helping her to get socialized, raise their voice for her children's education, and learn social skills. Thus, participation of women benefits inclusive development of any organizations and at the same time participation of women in different social forums have helped to capacitate themselves.

\section{Positive Changes Due to Women Participation (Comparison between the Two Schools)}

In the case of JSS, which is located in an urban city, many women are engaged in the governance structures. These women also have strong socio-economic positions in SMC and school administration. They could influence school decisions related to SMC, school administration, and structures of school governance. Both head and deputy head teachers seem self-motivated and positive thinkers. I (Principal author) observed that both are punctual and self-discipline at school. Due to this, other teachers, staff, and students come to school in time, engage in the teaching-learning process actively, try to reduce their absenteeism, and maintain self-discipline. Holger and Karen (2011) state that the active participation of women in education plays a central role in building capacity, improving the quality of education; and enhancing accountability. The women school leaders are the role models in school governance.

Three females in JSS (Sabina, Kunta, and Bika) are well capacitated and are holding the leadership position of school governance structures (SMC, PTA, School Administration, Exam Committee, etc.). Although their preceding years were full of struggles, they have developed a sound 
social network now. They have been raising funds for operating schools from different donors and collecting charities from government and non-governmental organizations, and individual donors. The raised fund and other resources have been used to construct infrastructures, manage salaries for privately funded teachers and other staff, manage educational materials (computers, lab, reading materials, etc.), and purchase furniture, and keep proper sanitation and hygiene system. Khanal (2009) also indicates that women from middle-class, elite groups get an opportunity to participate in school management actively. They control over the power and resource and contribute to managing funds as well which would support the good governance system of an institution.

The TSS is located in a semi-urban area in Lalitpur. There are no women in leadership positions of SMC, PTA, and School Administration. The school seems to make good academic and infrastructural development progress; however, it could be questioned whether the ongoing development process in the school is inclusive or not. Saud (2020) claims that influential capacity and a higher level of participation of the women members in the decision-making level plays a significant role to empower women and promote inclusive governance. Women's role and capacity to influence the decision and interests of the structures of school governance of TSS seem weak. It might be due to their socio-economic, educational status, and other factors. Hence, they could not contribute to raising funds and manage other resources for improving the governance situation of the school. Sharma (2008) also has a similar claim that if women's participation is at an active and higher level, they can contribute to fundraising initiatives to manage facilities and activities of schools well.

Meaningful participation of women in school governance is helpful to promote the overall education system. Rimal (2018) unveiled that women's participation should be active in holding the power and in controlling the decision-making and implementation process regarding the teaching and learning process of the school. They contribute to improving social justice through providing services and faculties related to sanitation, and hygiene practices (including menstruation hygiene) along with counseling, first aid, and restroom, and conducting a social audit to maintain the financial accountability of the school. However, Pandey (2016) pointed out that to mainstream the knowledge, skill, and experiences of the women from marginalized, oppressed, and subordinated groups, their participation in the decision-making process is essential. In line with Pandey, it could be agreed that to ensure gender balance and promote inclusive school governance, women's participation needs to be taken as their standpoint and socio-cultural context. Thereby by women's empowerment and acknowledgment of their ability to lead the social institutions is a matter of concern, to ensure their meaningful participation in any organizational structures including public school governance (Collins \& Sandoval, 1989 as cited by Harding, 2004).

\section{Participatory Development Practices}

The life experiences of the research participants have elucidated that women's participation contributes to a sound and inclusive school governance system. Participation in social institutions has empowered the women participants to understand and utilize their potentialities for the betterment of societies. Women's participation in school governance structures helps to uplift the social and economic status of crisis-affected people (Elahi \& Nawab, 2015), as Nepal reeled under a decade-long conflict until 2006. Nikkhah and Redzuan (2009) agree that participation and empowerment are the gateways for the community development process. Their meaningful participation in the community development process could be viewed as 'breaking the silence' which exists as women's culture of silence (Freire, 2005) in patriarchal societies. Their participation ensures their voice at public forums and makes social institutions accountable (Khadka, 2021). The initiation of gender-inclusive governance helps to achieve Goal 5 of the Sustainable development Goals, which is "achieve gender equality and empower all women and girls" (United Nations, 2021, p. 36). Thereby, women's participation in school governance in Nepal flourishes the inclusive education system and the empowerment of women themselves. Their collective voices make 
social institutions accountable which would break the patriarchal remnants in our society. These transformations in society are helpful in the community development process.

\section{Women Participation (A Ray of Hope in School Governance)}

This case study research in two public schools in Lalitpur, Nepal, reveals that to improve the inclusive-governance situation of the school, the position of women in school governance structures is the key contributing dimension of school governance. The participation theory posits that in the initial phase of participation, people do not have the power to influence the decision and lead the group, organization, and networks. This case study also posits that enabling environment has to be created so that women become able to contribute to promoting good governance practices in school. Alongside, women's participation can contribute to exploring different resources for public schools, the school environments can be made safe for girls' students and everyone, and participation itself helps to develop capacity development of women who are engaged in the governance structures. These positive changes in a society contribute to the overall development process. Thus, this could be interesting to know that the enabling environment for incessant participation contributes to empowering women which certainly would contribute to the good governance situation of the school.

To sum up, this research discloses that the meaningful participation of women in school governance contributes to improving its governance situation. The existing structural barriers which disempower women to participate in decision-making (Schwanke, 2013), still prevail in our society. When such barriers are lifted through the policies, women might make a noteworthy contribution in promoting sound governance in a school. Promotion of accountability, improved learning achievement, and the regularity of teachers and students are the other affirmative changes that were observed through the engagement of women in school governance structures.

\section{Note}

This article is based upon the MPhil thesis of the Principal author, Mr. Rishi Adhikari entitled "Women participation in school governance: An interpretive inquiry" submitted to Kathmandu University, Nepal in 2021. This MPhil thesis was supervised by Dr. Raj Kumar Dhungana. The Co-author, Mr. Devendra Adhikari has contributed to the section 'Participatory development practices' and worked as a corresponding author for this article.

\section{References}

Arnstein, S. R. (1969). A ladder of citizen participation. Journal of the American Planning Association, $35(4), 216-224$.

Chetri, T. B. (2017). Local democracy without elections: The politics in Nepal. Journal of Political Science, XVII, 63-81.

Elahi, N., Nyborg, I. L., \& Nawab, B. (2015). Participatory development practices: A critical analysis of gender empowerment and development in pre-and post-crises Swat, Pakistan. In Forum for Development Studies, 52(2),333-356). Routledge.

Freire, P. (2005). In M. B. Ramos (Ed.), Pedagogy of the oppressed (30th Anniversary edition). The Continuum International Publishing Group Inc. https://envs.ucsc.edu/internships/internshipreadings/freire-pedagogy-of-the-oppressed.pdf

Gaber, J. (2019). Building "A Ladder of Citizen Participation". Journal of the American Planning Association, 85(3), 188-201. https://doi.org/10.1080/01944363.2019. 1612267

Harding, S. (Ed.). (2004). The feminist standpoint theory reader: Intellectual and political controversies. Routledge. 
Haug, M. \&Aasland, A. (2015). Exploring dimensions of women's social exclusion and inclusion in Nepal. Forum for Development Studies, 43(2), 281-309. https://doi.org/10.1080/08039410.2015.1114517

Holger, D., \& Karen, M. (2011). Educational governance and participation with focus on developing countries. Institute of International Education, Department of Education, Stockholm University.

Joshi, M.S. (2018). Women Participation in political leadership in Sarada Municipality, Salyan[Unpublished Master's thesis]. Department of Conflict, Peace and Development Studies, Tribhuvan University. https://bit.ly/3q6OeVQ

Khadka, J. (2021). Effect of governance on educational performance in Nepal. Journal of Education and Research, 11(1), 97-114. https://doi.org/10.51474/jer.v11i1.502

Khanal, P. (2013). Community participation in schooling in Nepal: A disjunction between policy intention and policy implementation? Asia Pacific Journal of Education, 33(3), 235-248. https://doi.org/10.1080/02188791.2012.756390

Khanal, R. C. (2009). Community participation: Status and determinants; A case study from community managed schools in Doti districts, Nepal. https://bit.ly/3ou1uoC

Lewis, M., \&Gelander, G. P. (2009). Governance in Education: Raising Performance. SSRN Electronic Journal, 1-60. doi. 0.2139/ssrn.1992404

Maile, S. (2002). Accountability: An essential aspect of school governance. South African Journal of Education, 22(4), 326-331.

MercyCorps. (2009). Guide to good governance programming. https://www.mercycorps.org/sites/default/files/mcgoodgovernanceguide.pdf.

Ministry of Education, Science and Technology. (2016a). Education act 2028 (1971) $8^{\text {th }}$ amendment (2073). Kathmandu, Nepal: Authors.

Ministry of Education, Science and Technology. (2016b). Flash II report 2072(2015-016). Sanothimi, Bhaktapur, Nepal: Authors.

Ministry of Education, Science and Technology. (2016c). School sector development plan, Nepal, 20162023. Kathmandu, Nepal: Authors.

Ministry of Law, Justice and Parliamentary Affairs. (2017). Sikshyaain, 2028 B.S [Education act, 1971 with 9th amendment in 2017]. https://bit.ly/2NUjaXi

Munakarmi, R. (2015). Parental involvement in school: A case study of Kavre. Kathmandu University, Dhulikhel, Nepal.

Nekoka, M. (2006). Political participation and governance effectiveness: Does participation matter? Prague.

Nikkhah, H. A., \&Redzuan, M. (2009). Participation as a medium of empowerment in community development. European Journal of Social Sciences, 11(1), 170-176.

Pandey, B. (2016). Feminist standpoint and question of women participation in decision-making, in Nepal. Dhaulagiri Journal of Sociology and Anthropology, 10, 202-220. https://doi.org/10.3126/dsaj.v10i0.15886

Rimal, K. (2018). Perceptions and practices of female participation in school curriculum development process of Nepal[MPhil dissertation, Kathmandu University]. Kathmandu University, Dhulikhel, Nepal.

Saud, J. (2020). Representation and Participation in Local Governance in SudurPachhim Province of Nepal. Participation: A Nepalese Journal of Participatory Development, 22(20), 85-97. ISSN: 2565-4853

Schwanke, D. A. (2013). Barriers for women to positions of power: How societal and corporate structures, perceptions of leadership and discrimination restrict women's advancement to authority. Earth Common Journal, 3(2).

Nepalese Journal of Development and Rural Studies, Volume, 18, 2021 
Sharma, T. N. (2008). Structures and Mechanisms of community participation in school management. Journal of Education and Research, 1, 72-85. https://doi.org/10.3126/jer.v1i0.7954

Shrestha, K. N. (2014). Genuine efforts for quality in some community schools: Some case studies. Ministry of Education, Nepal.

Sijapati, D. B. (2019). Gender status in the community school of Nepal. Patan Pragya, 5(1), 209-218.

Terry, G., \& Thapa, N. (2012). Gender audit of Nepal's school sector reform programme. DFID Human Development Resource Centre Cambridge Education, DFID \& UKAID. https://bit.ly/3DuGeDG

Thanh, N. C., \& Thanh, T. T. L (2015). The Interconnection between interpretivist paradigm and qualitative methods in education. American Journal of Education Science, 1(2), 24-27. https://pdfs.semanticscholar.org/79e6/ 888e672cf2acf8afe2 ec21fd 42a29b2cbd90.pdf.

Thapa, V., \&Pathranarakul, P. (2019). Gender inclusiveness in disaster risk governance for sustainable recovery of 2015 Gorkha Earthquake, Nepal. International Journal of Disaster Risk Reduction, 34, 209-219.

United Nations. (2021). The sustainable development goals report 2021. https://bit.ly/3j9iXjp

Yin, R. K. (2014). Case study research: Design and methods (5 ${ }^{\text {th }}$ ed.). Sage Publication. 